\title{
Reduced noradrenaline turnover in streptozotocin-induced diabetic rats
}

\author{
T. Yoshida, H. Nishioka, Y. Nakamura and M. Kondo \\ First Department of Internal Medicine, Kyoto Prefectural University of Medicine, Kyoto, Japan
}

\begin{abstract}
Summary. To clarify whether activity of the sympathetic nervous system is decreased in streptozotocin-induced diabetic rats, noradrenaline turnover, which is a reliable indicator of sympathetic nervous system activity, was measured in the interscapular brown adipose tissue, heart and pancreas of streptozotocin diabetic rats. Results from studies using inhibition of noradrenaline biosynthesis with $\alpha$-methyl-p-tyrosine demonstrated significant reductions $(p<0.05-0.001)$ in sympathetic nervous system activity in the interscapular brown adipose tissue, heart and pancreas of streptozotocin $(65 \mathrm{mg} / \mathrm{kg})$ diabetic rats, compared with measurements in streptozotocin $(35 \mathrm{mg} / \mathrm{kg})$ diabetic and saline-control rats. The daily injections of neutral protamine Hagedorn insulin to streptozotocin $(65 \mathrm{mg} / \mathrm{kg})$ diabetic rats prevented the decrease of noradrena-
\end{abstract}

line turnover in the interscapular brown adipose tissue and heart significantly $(p<0.02)$, but this was less marked in pancreas, compared with non-treated streptozotocin $(65 \mathrm{mg} / \mathrm{kg})$ diabetic rats. Furthermore reduced noradrenaline turnover was also observed in the control rats which showed comparable changes in body weight to the rats injected with streptozotocin $(65 \mathrm{mg} / \mathrm{kg})$. These results suggest that poorly controlled streptozotocin diabetic rats may have reduced sympathetic nervous function, and that insulin therapy might prevent this.

Key words: Sympathetic nervous system activity, noradrenaline turnover, streptozotocin rat, brown adipose tissue, heart, pancreas, insulin.
Syndromes of diabetic neural involvement include sensory, motor and autonomic neuropathy and encephalopathy. Autonomic neuropathy leads to impotence, bladder dysfunction, gastrointestinal disturbances and orthostatic hypotension. Its development follows a similar time course to that of diabetic angiopathy [1] and is most often seen in those subjects who have had diabetes for 10-25 years [1]. Previous studies [2-7] show that diabetic patients with autonomic neuropathy have impaired sympathetic nervous system activity as shown by plasma catecholamine responses [2] and cardiovascular changes [3-6]. It has been reported recently, however, [8-11] that there are dissociations between adrenal medullary responses and noradrenaline (NA) turnover, which is a reliable indicator of sympathetic nervous system activity in peripheral tissues [12-16]. To date, data on NA turnover in diabetic patients and animals are less substantial. We therefore studied NA turnover in the interscapular brown adipose tissue, heart and pancreas of streptozotocin(STZ)-induced diabetic rats to clarify whether or not sympathetic nervous system activity was decreased.

\section{Materials and methods}

The 120 female Sprague-Dawley rats (weight approximately $220 \mathrm{~g}$, 8 -weeks old) used in these experiments were purchased from Charles River Japan Incorporation (Osaka, Japan) and were housed in a temperature-controlled room $\left(22 \pm 2^{\circ} \mathrm{C}\right)$ with artificial light from 0600 to $1800 \mathrm{~h}$. Commercial powdered chow (Charles River Japan) and tap water were available ad libitum for a 7-day period. Sixty of the rats were injected intravenously with streptozotocin (STZ, Upjohn, Kalamazoo, Michigan, USA) at a dose of $65 \mathrm{mg} / \mathrm{kg}$ (group 1), 24 at a dose of $35 \mathrm{mg} / \mathrm{kg}$ (group 2) and the remaining 36 with physiological saline (group 3). STZ, buffered to $\mathrm{pH} 4.5$ with a citrate buffer, was freshly prepared just before injection. The animals were then isolated in individual cages, with food and water ad libitum for a period of 14 days. The animals injected with STZ $(65 \mathrm{mg} / \mathrm{kg})$ developed symptoms of diabetes: hyperphagia, polydipsia, polyuria, glycosuria $(+++$ or ++++$)$ (Tes-Tape, Eli Lilly, Indianapolis, Indiana, USA) and hyperglycaemia $(17-38 \mathrm{mmol} / \mathrm{l})$, but those injected with STZ ( $35 \mathrm{mg} / \mathrm{kg}$ ) showed no hyperphagia, although they had mild glycosuria ( \pm or + ) and mild hyperglycaemia ( $8-12 \mathrm{mmol} / 1)$. Two weeks after administration of STZ, 24 rats injected with STZ $(65 \mathrm{mg} / \mathrm{kg})$ were injected with neutral protamine Hagedorn (NPH) insulin (Nordisk, Gentofte, Denmark) at doses of $2-8 \mathrm{U}$ every evening $(1800 \mathrm{~h})$ (group 4). Plasma glucose was measured once weekly at $1700 \mathrm{~h}$ and doses of insulin were adjusted as follows: plasma glucose $>$ $27.8 \mathrm{mmol} / \mathrm{l}, \mathrm{NPH}$ insulin - a dose of $8 \mathrm{U} ; 27.8-22.2 \mathrm{mmol} / 1-6 \mathrm{U}$ insulin; $22.2-16.7 \mathrm{mmol} / 1$ - $4 \mathrm{U}$ insulin; $16.7-11.1 \mathrm{mmol} / \mathrm{l}-2 \mathrm{U}$ insu- 
Table 1. Plasma glucose, insulin content, food intake and body and organ weights of STZ-treated and control rats at 8 weeks following STZ administration

$\begin{array}{lll}\text { Control rats } & \mathrm{STZ}(35 \mathrm{mg} / \mathrm{kg}) \text {-treated } & \mathrm{STZ}(65 \mathrm{mg} / \mathrm{kg}) \text {-treated } \\ (n=24) & \text { rats } & \text { rats } \\ & (n=24) & (n=24)\end{array}$

Plasma glucose $(\mathrm{mmol} / \mathrm{l})$

Insulin content (mU/g pancreas)

Food intake (g/day)

Body weight $(\mathrm{g})$

Interscapular brown adipose tissue $(\mathrm{g})$

Heart $(\mathrm{g})$

Pancreas $(\mathrm{g})$

$\begin{array}{rrr}6.4 & \pm 0.4 & 10.8 \pm 0.8^{\mathrm{b}} \\ 1025.4 \pm 54.2 & 418.4 \pm 118.1^{\mathrm{b}} \\ 25.1 \pm 5.2 & 25.0 \pm & \pm .4 \\ 304.1 \pm 8.4 & 269.4 \pm & \mathbf{4} .^{\mathrm{a}} \\ 0.25 \pm 0.01 & 0.21 \pm & 0.01^{\mathrm{a}} \\ 0.87 \pm 0.01 & 0.85 \pm & 0.02 \\ 0.56 \pm 0.02 & 0.54 \pm & 0.01\end{array}$

$34.5 \pm 1.4^{\mathrm{b}, \mathrm{d}}$
$23.4 \pm 11.2^{\mathrm{b}, \mathrm{d}}$
$55.4 \pm 6.9^{\mathrm{a}, \mathrm{d}}$
$210.2 \pm 5.9^{\mathrm{b}, \mathrm{d}}$
$0.10 \pm 0.01^{\mathrm{b}, \mathrm{d}}$
$0.66 \pm 0.01^{\mathrm{b}, \mathrm{d}}$
$0.45 \pm 0.01^{\mathrm{b}, \mathrm{d}}$

STZ $(65 \mathrm{mg} / \mathrm{kg})$-treated rats + insulin (at doses varying between $2-8 \mathrm{U}$ according to plasma glucose level) $(n=24)$

$\begin{aligned} 10.4 & \pm 0.8^{\mathrm{b}, \mathrm{f}} \\ 25.4 & \pm 13.6^{\mathrm{b}, \mathrm{d}} \\ 34.4 & \pm 5.8^{\mathrm{e}} \\ 245.3 & \pm 9.5^{\mathrm{b}, \mathrm{c}, \mathrm{f}} \\ 0.17 & \pm 0.01^{\mathrm{b}, \mathrm{d}, \mathrm{f}} \\ 0.75 & \pm 0.06^{\mathrm{b}, \mathrm{d}, \mathrm{f}} \\ 0.56 & \pm 0.02^{\mathrm{f}}\end{aligned}$

Values are shown as mean \pm SEM. These data are from the experiment depicted in Figure 1. F ratio of body and organ weights is as follows: body weight $\mathrm{F}_{3,92}=30.77, p<0.001$; interscapular brown adipose tissue $\mathrm{F}_{3,92}=39.78, p<0.001$; heart $\mathrm{F}_{3,92}=41.59, p<0.001$; pancreas $\mathrm{F}_{3,92}=16.72, p<$ $0.001{ }^{\mathrm{a}} p<0.05$ Significantly different from control; ${ }^{\mathrm{b}} p<0.001$ Significantly different from control; ${ }^{\mathrm{c}} p<0.05$ Significantly different from STZ $(35 \mathrm{mg} / \mathrm{kg})$-treated; ${ }^{\mathrm{d}} p<0.005$ Significantly different from STZ $(35 \mathrm{mg} / \mathrm{kg})$-treated; ${ }^{\mathrm{e}} p<0.05$ Significantly different from STZ $(65 \mathrm{mg} / \mathrm{kg})$-treated; ${ }^{f} p<0.005$ Significantly different from STZ $(65 \mathrm{mg} / \mathrm{kg})$-treated.

lin. Twelve control rats were pair-fed to produce comparable changes in body weight to the rats injected with $\mathrm{STZ}(65 \mathrm{mg} / \mathrm{kg})$. Eight weeks after the administration of STZ, body weight, food intake and plasma glucose were measured. Food intake was assessed for 3 days by weighing the food administered and subtracting the amount remaining at the end of a 24-h period for each rat. Plasma glucose was measured by an autoanalyzer (Beckman, Fullerton, California, USA), using a blood sample from the tail vein every evening $(1700 \mathrm{~h})$. Two days after the measurement of these parameters, the study of noradrenaline (NA) turnover began between 0900 and $1000 \mathrm{~h}$. The methyl ester of $\alpha$-methyl-p-tyrosine $(80 \mathrm{mg} / \mathrm{kg}$, Sigma Chemicals, St. Louis, MO, USA) was diluted in saline and administered intraperitoneally. At time 0 and at 3 and $6 \mathrm{~h}$ following this injection, four to eight animals from each experimental group were killed by cervical dislocation. The interscapular brown adipose tissue, heart and pancreas were removed rapidly and dissected from the connective tissue, weighed and homogenized in ice-cold $0.1 \mathrm{~N}$ perchloric acid containing $0.1 \mathrm{mmol} / 1 \mathrm{re}-$ duced glutathione in a polytron (Kinematica, Luzern, Switzerland) and centrifuged at $27000 \mathrm{~g}$ for $5 \mathrm{~min}$ at $0^{\circ} \mathrm{C}$. Aliquots of the supernatant were stored at $-70^{\circ} \mathrm{C}$ for later determination of NA (within 1 week). For measurement of insulin content of the pancreas [17], a part was excised, weighed and homogenized in $10 \mathrm{vol}$ of ice-cold acidethanol (HCL $0.2 \mathrm{~N}$, ehtanol $75 \%$ ) in a polytron. The suspension was shaken overnight at $4^{\circ} \mathrm{C}$. After centrifugation at $1500 \mathrm{~g}$ for $20 \mathrm{~min}$ at $4^{\circ} \mathrm{C}$, the supernatants were stored at $-70^{\circ} \mathrm{C}$ for later determination of insulin. NA was assayed radioenzymatically, using a minor modification [16] of the method of Peuler and Johnson [18]; the sensitivity of the assay is 1-2 pg for NA. It is based on the use of isolated catecholO-methyltransferase to transfer a radioactive methyl group from adenosyl-L-methionine, S-(methyl $\left.-{ }^{3} \mathrm{H}\right)$ to an endogenous catecholamine receptor to form a radioactive $\mathrm{O}$-methyl catecholamine derivative. Insulin was measured by radioimmunoassay using a double-antibody method [19].

\section{Statistical analysis}

Data are presented as mean \pm SEM. Statistical analyses were performed using analysis of variance and of covariance [20]. In the NA turnover study the data were plotted semi-logarithmically. The slope (fractional NA turnover rate, $k$ ) of the decline in endogenous NA after $\alpha$-methyl-p-tyrosine injection was calculated by the method of least squares [20]. The statistical significance of each computed regression line was assessed by analysis of variance. Comparison of fractional turnover rates was made by an analysis of covariance. NA turnover rates were calculated as the product of the fractional turnover rate $(\mathrm{k}) \times$ the endogenous NA content at time $0[21,22]$. Ninety-five percentage confidence intervals were determined for NA turnover rates [23].

\section{Results}

Plasma glucose, insulin content, food intake and body and organ weights of STZ-treated and control rats at 8 weeks following STZ administration are shown in Table 1. Plasma glucose levels of the STZ-treated groups were significantly higher than in the control rats. That of STZ $(65 \mathrm{mg} / \mathrm{kg}$ )-treated rats (group 1) was markedly higher than in the STZ $(35 \mathrm{mg} / \mathrm{kg})$-treated rats (group 2) and STZ (65 mg/kg)-treated rats administered insulin (group 4). Insulin content decreased significantly in group 1 and 4 compared with group 2 and control rats (group 3). However, that of the STZ (35 mg/ $\mathrm{kg}$ )-treated rats (group 2) was lower than those in the control group (group 3). The food intake of STZ $(65 \mathrm{mg} / \mathrm{kg})$-treated group (group 1) was significantly increased compared with other groups (group 2, 3 and 4). The body weights of the STZ-treated groups were significantly less than the control rats and additionally, the body weights of STZ $(65 \mathrm{mg} / \mathrm{kg}$ )-treated group (group 1 and 4) were significantly less than those of the STZ (35 mg/ $\mathrm{kg}$ )-treated rats (group 2). Weights of the interscapular brown adipose tissue, heart and pancreas in STZ $(65 \mathrm{mg} / \mathrm{kg}$ )-treated rats (group 1) were significantly less than those of STZ (35 mg/ $\mathrm{kg}$ )-treated (group 2) and control rats (group 3). Insulin injection into STZ $(65 \mathrm{mg} / \mathrm{kg})$-treated animals prevented reduction of organ weight (group 4).

NA turnover data from the interscapular brown adipose tissue, heart and pancreas of STZ-treated and saline control rats are summarized in Figure 1 and Table 2.

Endogenous NA levels in the interscapular brown adipose tissue, heart and pancreas of the STZ (65 mg/ 


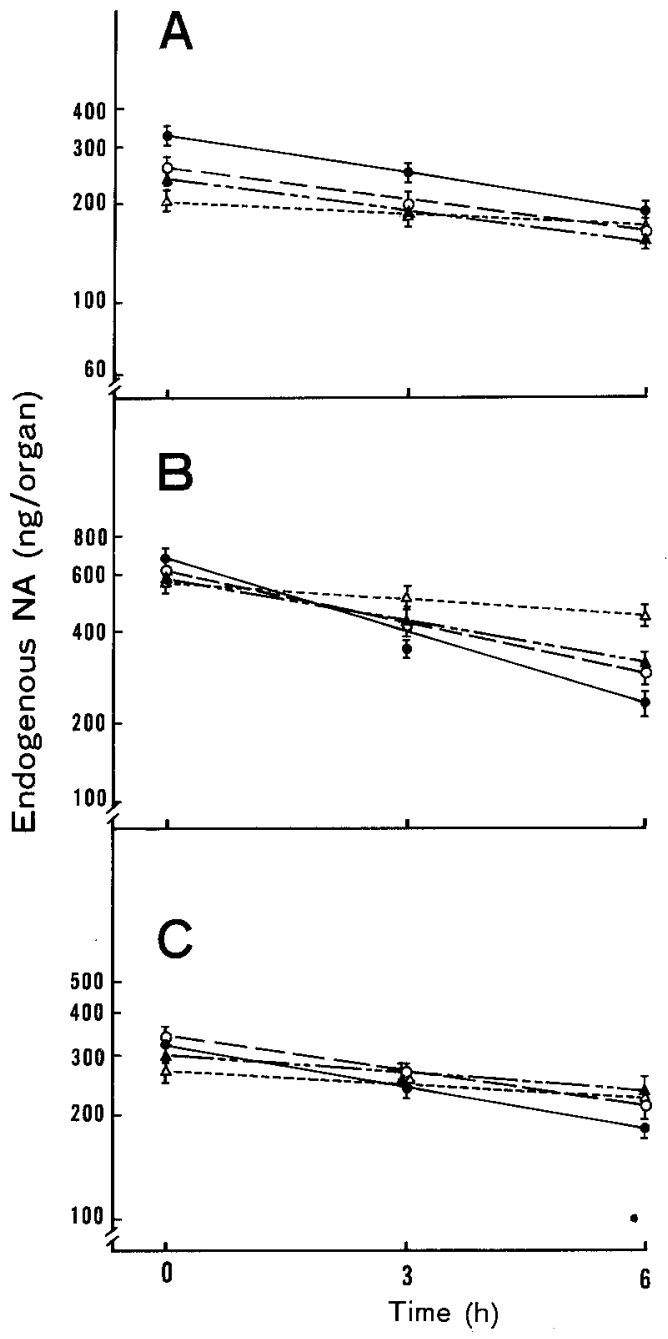

Fig. 1A-C. NA turnover in the interscapular brown adipose tissue (A), heart (B) and pancreas (C) of STZ-treated and saline control rats. NA turnover was measured in the interscapular brown adipose tissue, heart and pancreas from STZ $(65 \mathrm{mg} / \mathrm{kg})$-treated $(\Delta----\Delta)$, STZ $(65 \mathrm{mg} / \mathrm{kg}$ )-treated with daily NPH insulin injections (at doses varying between $2-8 \mathrm{U}$ according to plasma glucose level $(\boldsymbol{\Delta}-\cdots-\boldsymbol{\Delta})$, STZ $(35 \mathrm{mg} / \mathrm{kg})$-treated $\left(\mathrm{O}-\mathrm{O}_{\mathrm{O}}\right)$ and saline control $(-\infty)$ rats fed ad libitum for 8 weeks after STZ or saline administration. All data are plotted as mean \pm SEM for endogenous NA in tissues from eight animals in each group after injection of $\alpha$-methyl-p-tyrosine $(80 \mathrm{mg} /$ $\mathrm{kg}$ ). The null hypothesis that all four regression lines could be represented by a common one was rejected for the interscapular brown adipose tissue $\left(F_{3,88}=9.68, \mathbf{p}<0.001\right)$, heart $\left(F_{3,88}=12.07, \mathbf{p}<0.001\right)$ and pancreas $\left(\mathrm{F}_{3,88}=4,00, \mathrm{p}<0.05\right)$

$\mathrm{kg}$ )-treated group (group 1) were less than those of the control group (group 3). The fractional turnover rates $(\mathrm{k})$ in the interscapular brown adipose tissue, heart and pancreas of the STZ (65 mg/ $\mathrm{kg}$ )-treated group (group 1) were much slower than those of control animals (group 3) and those in the interscapular brown adipose tissue of STZ (35 mg/kg)-treated group (group 2). Total NA turnover was significantly decreased by STZ $(65 \mathrm{mg} / \mathrm{kg}$ ) treatment (group 1$)$, but no significant difference was observed between the STZ $(35 \mathrm{mg}$ / $\mathrm{kg}$ )-treated (group 2) and the control groups (group 3). Daily insulin injections to STZ $(65 \mathrm{mg} / \mathrm{kg})$-treated rats prevented a decrease in NA turnover of the interscapular brown adipose tissue and heart, but not in the pancreas significantly. The NA turnover data in STZ $(65 \mathrm{mg} / \mathrm{kg})$-treated and control (pair-fed) rats are shown in Table 3 . Control rats were fed approximately one-ninth the amount of food $(5.9 \pm 1.4 \mathrm{~g} /$ day) to produce comparable changes in body weight to those of $\mathrm{STZ}(65 \mathrm{mg} / \mathrm{kg})$-treated rats $(53.8 \pm 7.1 \mathrm{~g} /$ day $)$ and this amount was one-quarter that taken by control animals fed ad libitum $(25.1 \pm 5.2 \mathrm{~g} /$ day $)$ as shown in Table 1 . Weights of the interscapular brown adipose tissue, heart and pancreas in STZ $(65 \mathrm{mg} / \mathrm{kg})$-treated animals were significantly less. The NA content of these tissues was greater in the paired controls than in STZ $(65 \mathrm{mg}$ / $\mathrm{kg}$ )-treated rats, but NA turnover was similar since there was no increase involved.

\section{Discussion}

This study shows that, in poorly controlled STZ-induced diabetic rats, NA turnover was reduced significantly in the interscapular brown adipose tissue, heart and pancreas, compared with those of mild STZ-diabetic and control rats, and that daily injections of NPH insulin to poorly-controlled diabetic rats prevented the decreased NA turnover in the interscapular brown adipose tissue and heart, but had less effect in pancreas.

The use of NA turnover techniques to assess the functional state of the unperturbed sympathetic nervous system permits the estimation of organ-specific sympathetic activity in each sympathetically innervated organ. NA, the sympathetic neurotransmitter, is synthesized and stored within the sympathetic nerve endings and is released in response to neural impulses. An active transport mechanism in the neuronal membrane recaptures a major fraction of the released NA. As the activities of both NA biosynthesis and NA re-uptake are coupled to the level of impulse traffic, the endogenous level of NA within the nerve terminals in a particular organ is relatively constant despite wide fluctuations in sympathetic activity. Kinetic measurements of NA turnover use these neuronal processes of NA biosynthesis and active transport to quantitate changes in the level of sympathetic activity in experimental conditions. The ${ }^{3} \mathrm{H}$-NA turnover technique involves the intravenous administration of tracer doses of ${ }^{3} \mathrm{H}-\mathrm{NA}$. After uptake of the label into the sympathetic nerve endings and equilibration with intraneuronal stores, the rate of disappearance of the tracer provides an indication of sympathetic activity within a particular organ. A second method of assessing NA turnover involves inhibition of NA biosynthesis with $\alpha$-methyl-p-tyrosine, an inhibitor of tyrosine hydroxylase, the rate-limiting step in NA biosynthesis. In the presence of such inhibition endogenous NA levels cannot be maintained and the rate of fall of endogenous NA reflects NA turnover [13]. Intraneuronal metabolism of NA contributes to a limited 
Table 2. NA content and NA turnover in the interscapular brown adipose tissue, heart and pancreas of STZ-treated and control rats

\begin{tabular}{|c|c|c|c|}
\hline & $\begin{array}{l}\text { Endogenous NA } \\
\text { (ng/organ) }\end{array}$ & $\begin{array}{l}\mathrm{k} \\
\left(\% \cdot \mathrm{h}^{-1}\right)\end{array}$ & $\begin{array}{l}\text { NA turnover rate } \\
\left(\mathrm{ng} \cdot \operatorname{organ}^{-1} \cdot \mathrm{h}^{-1}\right)\end{array}$ \\
\hline \multicolumn{4}{|l|}{ Interscapular brown adipose tissue } \\
\hline Control & $326.1 \pm 8.5$ & $9.5 \pm 1.0$ & $31 \pm 4$ \\
\hline $\mathrm{STZ}(35 \mathrm{mg} / \mathrm{kg})$-treated & $260.9 \pm 5.6^{\mathrm{a}}$ & $7.3 \pm 1.2$ & $19 \pm 4$ \\
\hline STZ $(65 \mathrm{mg} / \mathrm{kg})$-treated & $204.6 \pm 5.6^{\mathrm{a}, \mathrm{c}}$ & $2.4 \pm 0.5^{\mathrm{a}, \mathrm{c}}$ & $5 \pm 1$ \\
\hline $\begin{array}{l}\mathrm{STZ}(65 \mathrm{mg} / \mathrm{kg}) \text {-treated }+ \text { Insulin } \\
\text { (at doses varying between } 2-8 \mathrm{U} \\
\text { according to plasma glucose level) }\end{array}$ & $248.3 \pm 5.2^{\mathrm{a}, \mathrm{d}}$ & $6.8 \pm 1.1^{\mathrm{d}}$ & $17 \pm 3$ \\
\hline \multicolumn{4}{|l|}{ Heart } \\
\hline Control & $667.5 \pm 31.7$ & $18.0 \pm 1.7$ & $120 \pm 18$ \\
\hline STZ $(35 \mathrm{mg} / \mathrm{kg})$-treated & $604.8 \pm 35.9$ & $12.1 \pm 3.5$ & $73 \pm 27$ \\
\hline $\mathrm{STZ}(65 \mathrm{mg} / \mathrm{kg})$-treated & $560.6 \pm 21.4^{\mathrm{b}}$ & $4.0 \pm 1.2^{\mathrm{a}}$ & $22 \pm 8$ \\
\hline STZ (65 mg/kg)-treated + Insulin & $567.8 \pm 23.2^{b}$ & $10.0 \pm 1.1^{\mathrm{b}, \mathrm{d}}$ & $57 \pm 9$ \\
\hline \multicolumn{4}{|l|}{ Pancreas } \\
\hline Control & $319.0 \pm 13.6$ & $9.3 \pm 1.4$ & $30 \pm 6$ \\
\hline $\mathrm{STZ}(35 \mathrm{mg} / \mathrm{kg})$-treated & $342.4 \pm 19.1$ & $8.4 \pm 1.3$ & $29 \pm 6$ \\
\hline STZ $(65 \mathrm{mg} / \mathrm{kg})$-treated & $269.5 \pm 14.2^{b, c}$ & $3.4 \pm 1.2^{\mathrm{b}}$ & $9 \pm 4$ \\
\hline STZ (65 mg/kg)-treated + Insulin & $306.0 \pm 16.1$ & $5.6 \pm 1.5$ & $17 \pm 6$ \\
\hline
\end{tabular}

The fractional NA turnover rate $(\mathrm{k})$ is expressed as mean \pm SEM. The NA turnover rate is expressed as the mean with $95 \%$ confidence limits. Eight rats were used at each time point. Endogenous NA is the value of time point $0 .{ }^{\mathrm{a}} p<0.001$ Significantly different from control; ${ }^{\mathrm{b}} p<0.05$ Significantly different from control; ${ }^{c} p<0.01$ Significantly different from STZ (35 mg/ $\left./ \mathrm{kg}\right)$-treated; ${ }^{\mathrm{d}} p<0.02$ Significantly different from STZ $(65 \mathrm{mg} / \mathrm{kg})$-treated

Table 3. Body weight, food intake, NA content and NA turnover rate in STZ $(65 \mathrm{mg} / \mathrm{kg})$-treated and control (pair-fed) rats

\begin{tabular}{|c|c|c|}
\hline & $\begin{array}{l}\mathrm{STZ}(65 \mathrm{mg} / \mathrm{kg}) \text {-treated } \\
\text { rats } \\
(n=12)\end{array}$ & $\begin{array}{l}\text { Control rats } \\
\text { (pair-fed) } \\
(n=12)\end{array}$ \\
\hline Body weight (g) & $223.4 \pm 10.9$ & $221.9 \pm 10.3$ \\
\hline Food intake (g/day) & $53.8 \pm 7.1^{\mathrm{b}}$ & $5.9 \pm 1.4$ \\
\hline \multicolumn{3}{|c|}{$\begin{array}{l}\text { Interscapular brown adipose } \\
\text { tissue }\end{array}$} \\
\hline $\begin{array}{l}\text { Weight }(\mathrm{g}) \\
\text { NA }(\text { ng/organ }) \\
\mathrm{k}(\% / \mathrm{h}) \\
\text { NA turnover rate } \\
\left(\text { ng } \cdot \text { organ }^{-1} \cdot \mathrm{h}^{-1}\right)\end{array}$ & $\begin{aligned} 0.10 \pm 0.01^{\mathrm{b}} & \pm 12.7^{\mathrm{a}} \\
212.8 & \pm 12.7^{2} \\
3.4 & \pm 1.2 \\
7 & \pm 3\end{aligned}$ & $\begin{aligned} 0.12 & \pm 0.01 \\
276.8 & \pm 21.3 \\
4.9 & \pm 1.3 \\
14 & \pm 5\end{aligned}$ \\
\hline \multicolumn{3}{|l|}{ Heart } \\
\hline $\begin{array}{l}\text { Weight }(\mathrm{g}) \\
\text { NA }(\mathrm{ng} / \text { organ }) \\
\mathrm{k}(\% / \mathrm{h}) \\
\text { NA turnover rate } \\
\left(\mathrm{ng} \cdot \text { organ }^{-1} \cdot \mathrm{h}^{-1}\right)\end{array}$ & $\begin{aligned} 0.67 & \pm 0.02^{\mathrm{a}} \\
599.8 & \pm 23.8^{\mathrm{b}} \\
4.1 & \pm 1.3 \\
25 & \pm 9\end{aligned}$ & $\begin{aligned} 0.73 & \pm 0.02 \\
846.8 & \pm 24.9 \\
2.8 & \pm 1.5 \\
24 & \pm 13\end{aligned}$ \\
\hline \multicolumn{3}{|l|}{ Pancreas } \\
\hline $\begin{array}{l}\text { Weight }(\mathrm{g}) \\
\text { NA (ng/organ) } \\
\mathrm{k}(\% / \mathrm{h}) \\
\text { NA turnover rate } \\
\left(\mathrm{ng} \cdot \text { organ }^{-1} \cdot \mathrm{h}^{-1}\right)\end{array}$ & $\begin{aligned} 0.44 & \pm 0.02^{\mathrm{a}} \\
281.8 & \pm 18.8^{\mathrm{b}} \\
4.5 & \pm 2.0 \\
13 & \pm 7\end{aligned}$ & $\begin{aligned} 0.51 & \pm 0.02 \\
498.5 & \pm 29.8 \\
4.2 & \pm 1.4 \\
21 & \pm 9\end{aligned}$ \\
\hline
\end{tabular}

Values are shown as mean \pm SEM. The NA turnover rate is expressed as the mean with $95 \%$ confidence limits. At time 0 and at 3 and $6 \mathrm{~h}$ following the administration of $\alpha$-methyl-p-tyrosine, four rats from each experimental group were used to obtain turnover data. NA content is the value time point 0 . Body weights at the beginning of the experiment were similar in these groups; STZ $(65 \mathrm{mg} / \mathrm{kg})$-treated rats weighed $216.9 \pm 2.9 \mathrm{~g}$ and control animals $218.3 \pm 2.8 \mathrm{~g} .{ }^{\mathrm{a}} p<0.05 \mathrm{Sig}-$ nificantly different from control; ${ }^{b} p<0.005$ Significantly different from control extent to these measurement of NA turnover, but is not altered by the experimental conditions of feeding and fasting [13] described here.

We found previously, in obese (ob/ob) and lean mice [24], that NA turnover in the interscapular brown adipose tissue and heart by ${ }^{3} \mathrm{H}-\mathrm{NA}$ administration was consistent with that observed with NA synthesis inhibition with $\alpha$-methyl-p-tyrosine. In the present study the NA synthesis inhibition technique for measuring NA turnover was used. Our present findings therefore suggest that sympathetic nervous system activity is reduced in the interscapular brown adipose tissue, heart and pancreas of poorly controlled STZ-diabetic rats. These results are consistent with the indirect data reported previously $[1-7,25,26]$, and are in harmony with the report of Giachetti [27] using spontaneous diabetic mice, and with other reports which showed decreased sympathetic nervous system activity in the interscapular brown adipose tissue [28] and pancreas [29] of STZ rats.

In our experiment, using STZ $(65 \mathrm{mg} / \mathrm{kg})$-treated and control rats that were pair-fed, there was no significant difference in reduced NA turnover, although food intake in the control group was restricted to one-ninth of that of STZ $(65 \mathrm{mg} / \mathrm{kg})$-treated rats, and one quarter of that of the control animals fed ad libitum. It is well known that NA turnover is decreased by fasting [14]. In our previous study [16], using lateral hypothalamic (appetite-centre)-lesioned rats, control rats which were pair fed by semi-starvation with lateral hypothalamiclesioned rats for 3 weeks showed a much reduced NA turnover in the interscapular brown adipose tissue, heart and pancreas. Therefore, the present results in 
control rats that were pair fed with STZ $(65 \mathrm{mg}$ / $\mathrm{kg}$ )-treated animals agrees with the data of control rats in the lateral hypothalamic lesion study [16]. It is also well known that NA turnover is increased by overfeeding $[13,30,31]$. Although our poorly controlled STZdiabetic rats were marked hyperphagic, as with previous reports [32,33], they had decreased NA turnover. These findings suggest an important role for insulin in coordinating sympathetic nervous system activity with dietary intake. Daily injections of insulin to severe diabetic rats prevented a decrease in NA turnover in the interscapular brown adipose tissue and heart, but was less effective in the pancreas, although NA turnover in the pancreas did tend to increase with injection of insulin. This suggests that replacement insulin therapy may prevent a decrease in sympathetic nervous system activity in severe diabetic animals and may also prevent autonomic neuropathy.

Acknowledgements. We thank Ms. S.Ohnishi and M.Hori for their technical help. This research was supported in part by a grant from Mitsui Life Social Welfare Foundation, Japan (1984).

\section{References}

1. Christensen NJ (1979) Catecholamine and diabetes mellitus. Diabetologia 16: $211-224$

2. Christensen NJ (1972) Plasma catecholamines in long-term diabetics with and without neuropathy and in hypophysectomized subjects. J Clin Invest 51:779-787

3. Christensen NJ (1983) Acute effects of insulin on cardiovascular function and noradrenaline uptake and release. Diabetologia 25 : 377-381

4. Neubauer B, Christensen NJ (1976) The noradrenaline, adrenaline and dopamine content in the cardiovascular system in longterm diabetics. Diabetes 25: 6-10

5. Gundersen HJG, Neubauer B (1977) A long-term diabetic autonomic nervous abnormality. Reduced variations in resting heart rate measured by a simple and sensitive method. Diabetologia 13: 137-140

6. Wheele T, Watkins PJ (1973) Cardiac denervation in diabetes. $\mathrm{Br}$ Med J 4: 584-586

7. Gundersen HJG (1974) An abnormality of the central autonomic nervous system in long-term diabetes: absence of hippus. Diabetologia 10: 366 (Abstract)

8. Young JB, Landsberg L (1979) Sympathoadrenal activity in fasting pregnant rats: Dissociation of adrenal medullary and sympathetic nervous system responses. J Clin Invest 64: 109-116

9. Rappaport EB, Young JB, Landsberg L (1982) Effect of 2-deoxyD-glucose on the cardiac sympathetic nerves and the adrenal medulla in the rat: further evidence for a dissociation of sympathetic nervous system and adrenal medullary responses. Endocrinology 110: $650-656$

10. Young JB, Fish S, Landsberg L (1983) Sympathetic nervous system and adrenal medullary responses to ischemic injury in mice. Am J Physiol 245: E67-E73

11. Young JB, Rosa RM, Landsberg L (1984) Dissociation of sympathetic nervous system and adrenal medullary responses. Am J Physiol 247: E35-E40

12. Spector S, Sjoerdsma A, Udenfriend S (1965) Blockade of endogenous norepinephrine synthesis by alpha-methyl-tyrosine, an inhibition of tyrosine hydroxylase. J Pharmacol Exp Ther 147: 86-95

13. Young JB, Landsberg L (1977) Stimulation of sympathetic ner- vous system during sucrose feeding. Nature (London) 269: 615-617

14. Young JB, Landsberg L (1977) Suppression of sympathetic nervous system during fasting. Science 196: 1473-1475

15. Avakian EV, Horvath SM (1981) Starvation suppresses sympathoadrenal medullary response to cold exposure in rats. Am J Physiol 241: E316-E320

16. Yoshida T, Kemnitz JW, Bray GA (1983) Lateral hypothalamic lesions and norepinephrine turnover in rats. J Clin Invest 72 : 919-927

17. Mirsky IA (1973) Insulin: purification and biochemical characterization. In: Berson SA (ed) Methods in investigative and diagnostic endocrinology, Vol2B. American Elsevier, New York, pp 823-883

18. Peuler JD, Johnson GA (1977) Simultaneous single isotope radioenzymatic assay of plasma norepinephrine, epinephrine and dopamine. Life Sci 21: 625-636

19. Hales CN, Randle PJ (1963) Immunoassay of insulin with insulin antibody precipitate. Biochem J 88: 137-146

20. Zar JH (1974) Biostatistical analysis. Prentice-Hall, Englewood Cliffs, New Jersey, pp 41-235

21. Brodie BB, Costa E, Dlabac A, Neff NH, Smookler HH (1966) Application of steady state kinetics to the estimation of synthesis rate and turnover time of tissue catecholamine. J Pharmacol Exp Ther 154: 493-498

22. Neff NH, Tozer TN, Hammer W, Costa E, Brodie BB (1968) Application of steady-state kinetics to the uptake and decline of ${ }^{3} \mathrm{H}-$ $\mathrm{NE}$ in the rat heart. $J$ Pharmacol Exp Ther 160: 48-52

23. Taubin HL, Djahanguiri B, Landsberg L (1972) Noradrenaline concentration and turnover in different regions of the gastrointestinal tract of the rat: an approach to the evaluation of sympathetic activity in the gut. Gut 13:790-795

24. Vander Tuig JG, Ohshima K, Yoshida T, Romsos DR, Bray GA (1984) Adrenalectomy increases norepinephrine turnover in brown adipose tissue of obese (ob/ob) mice. Life Sci 34: $1423-1432$

25. Seydoux J, Chinet A, Schneider-Picard G, Bas S, Imesch E, Assimacopoulos-Jeannet F, Giacobino JP, Girardier L (1983) Brown adipose tissue metabolism in streptozotocin diabetic rats. Endocrinology 113: 604-610

26. Rothwell NJ, Stock MJ (1981) A role for insulin in diet-induced thermogenesis of cafeteria-fed rats. Metabolism 30:673-678

27. Giachetti A (1978) The functional state of sympathetic nerves in spontaneously diabetic mice. Diabetes 27:969-974

28. Young JB, Einhorn D, Landsberg L (1983) Decreased sympathetic (SNS) activity in interscapular brown adipose tissue (IBAT) of streptozotocin-treated rats. Diabetes 32 (Suppl 1): 26 A (Abstract)

29. Nadeau A, Tancrede G, Trudel D, Jobidon C, Nguyen MH, Rousseau-Migneron S (1983) Decreased sympathetic activity in the pancreas of streptozotocin-diabetic rats. Diabetes 32 (Suppl 1): 146 A (Abstract)

30. Yoshida T, Bray GA (1984) Catecholamine turnover in rats with ventromedial hypothalamic lesions. Am J Physiol 246: R558-R565

31. Young JB, Saville E, Rothwell NJ, Stock MJ, Landsberg L (1982) Effect of diet and cold exposure on norepinephrine turnover in brown adipose tissue of the rat. J Clin Invest 69: 1061-1071

32. Hernandez L, Briese E (1979) Analysis of diabetic hyperphagia and polydipsia. Physiol Behav 9: 741-746

33. DeCastro JM, Balagura S (1975) Meal patterning in the streptozotocin-diabetic rats. Physiol Behav 15: 259-263

Received: 12 February 1985

and in revised form: 5 June 1985

Dr. T. Yoshida

First Department of Internal Medicine

Kyoto Prefectural University of Medicine

Kyoto

Japan 